\title{
War is Not Inevitable - Why War Revisited
}

\author{
*Henri Parens \\ Professor of Psychiatry, Thomas Jefferson University, USA \\ Submission: February 27, 2017; Published: March 16, 2017 \\ *Corresponding author: Henri Parens, Professor of Psychiatry, Thomas Jefferson University, Bala Cynwyd, PA 19004, Philadelphia, USA, \\ Tel: 1-610-664-5220; Email: handrparens@verizon.net
}

Abstract

In 1932, Freud [1] told Einstein that war is inevitable because humans have an instinct to destroy. However, studies of aggression reveal that rather than being an inborn drive, destructiveness is generated in us by experiences of excessive psychic pain. In War Is Not Inevitable I discuss and document core psychodynamics that lead groups to war. Detailing some of the psychodynamics that led from World War I to World War II and their respective aftermath, I address how major factors that gave rise to these wars must, can, and have been counteracted. In doing so, War is Not Inevitable considers strategies by which civilization has and is constructively preventing wars, as well as the need for further innovative efforts to achieve that end.

Abbreviations: HA: Hostile Aggression; HD: Hostile Destructiveness; WWI: World War I; WWII: World War II

\section{Introduction}

The editors to "Why War?" (S.E. XXII) note that Einstein was among those "Invited in 1931 by the International Institute of Intellectual Cooperation of the Permanent Committee for Literature \& the Arts of the League of Nations to exchange letters between intellectuals to serve the common interests of the League of Nations and of intellectual life" [1]. Having elected to discuss his selected question with Freud, in a letter dated 30th July 1932, Einstein asked Freud: "Is there any way of delivering mankind from the menace of war"?

Freud's answer in essence was, “...to the best of my knowledge-and conjecture...When human beings are incited to war they may have a whole number of motives for assenting.... A lust for aggression and destruction is certainly among them: the countless cruelties in history and in our everyday lives vouch for its existence and its strength". I draw your attention to Freud's pondering his own statement in his inversion of the "cause à effect" principle. He goes on, "As a result of a little speculation, we have come to suppose that this [destructive] instinct is at work in every living creature...striving to bring it...to its original [inorganic state]. Thus it...deserves to be called a death instinct". And Freud tells us that the life instincts compel the organism to turn this inborn destructiveness onto the external world.

But we must note that in 1920 and 1925, Freud [2,3] wrote that, at times what he put forward is speculation not proved by his own clinical research-and he urged us to take up the task of proof. For example, in Beyond the Pleasure Principle, Freud [2] starts Section IV with, "What follows is speculation, often farfetched speculation, which the reader will consider or dismiss according to his...predilection". Then as he moves to close this major work, in Section VI, he tells us that his 'speculation' has gone far enough. But he adds: "Not, however, without the addition of a few words of critical reflection. It may be asked... how far I am myself convinced of the truth of the hypotheses that have been set out in these pages. My answer would be that I am not convinced myself and that I do not seek to persuade other people to believe in them....More precisely, I do not know how far to believe in them". Nonetheless, in Civilization and Its Discontents Freud writes, "despite the resistance met with even in analytic circles," the death instinct has "gained such a hold on me that I can no longer think in any other way" [4]. Freud [5] re-iterated this statement in 1937 in a letter to Marie Bonaparte.

I have entitled chapter 1 of War is Not Inevitable, "The problem with Freud's answer to Einstein's question, 'Why War': it was wrong". Let me here start by saying again that Freud supports his speculative answer with an inversion of the "cause à effect" principle, proposing that"...the countless cruelties in history and in our everyday lives vouch [i.e. document that] a death instinct". To date, no study findings, clinical, empirical, or bio-medical have proven that a death instinct is the cause for our 
patients' self-destructiveness or outer directed destructiveness, nor for the countless cruelties in history. I am of course far from the first to doubt the death instinct basis of aggression given that from the 1940s on a number of analysts [6-10] held that our psychoanalytic patients' materials would never hold proof that their destructiveness is driven by a death instinct. As Freud tells us [4], even since 1930 quite a number of analysts have rejected the death-instinct basis of aggression [11].

In sum, as I say in my book "Let me [apologize] for knowingly deceiving you by saying that Freud's answer "was wrong"; I did so in order to engage your interest. One cannot say that Freud's answer was wrong-because one cannot disprove an un-provable hypothesis, and hypothesis unproven to this day. I am not on the side of dogmatism that holds that only what is provable is true. The fact is that while we don't know all we need to know about the structure of the atom, we've nonetheless made remarkable advance in nuclear science" [12]. All in all, I say that the death instinct 'hypothesis' of aggression must be accepted on faith or be rejected. Until sustainable causal evidence is brought forward, I will hold that the "death instinct theory" of aggression is not a "theory". In 1920, as he did in 1925, Freud [2,3] gave us a speculation, an "hypothesis of aggression" which he left for us to prove.

But foremost, my assertion that the hypothesis is wrong is supported by the results of a 37 year-long research project on the development of aggression in early childhood, in which, observing infants from birth on, I could see no evidence of spontaneous manifestations of destructiveness . Our study started in 1970; we carried it out directly over a period of 7 years, meeting with 10 mothers and their eventual 16 newborns, for 2-hour sessions, twice weekly, for 11 months of each year, with follow-up studies at 19, 32, and 37 years $[11,13,14]$. The findings from this small-but-long-term-study generated the following, provable and replicable theory of aggression.

\section{The Multi-Trends Theory of Aggression: A Working Model of Human Aggression [13,15]}

The Multi-trends theory of aggression holds that aggression is a biologically generated inner pressure to act upon, control, and master self and environment. Looking at aggressive behaviors in children from birth on, we catalogued these behaviors into four categories:

a) Non-destructive aggression (pressured sensori-motor activity-evident from 15 weeks on);

b) Non-affective destructiveness (feeding activity-evident from birth on);

c) Unpleasure-related destructiveness (rage reaction of infancy-evident from birth on); and

d) Pleasure-related destructiveness (teasing and taunting activity-evident from about 11 months on).
In the leap from data to hypothesis, I propose that there are three trends in aggression:

I. Non-destructive aggression (a),

II. Non-affective destructiveness (b)-I hold that we cannot have a theory of aggression without taking "prey aggression" into account,

III. Hostile Aggression (c and d).

a. Non-destructive aggression is inborn, biologically generated; essential for adaptation; fuels mastery of self and environment, fuels assertiveness and drives us to achieve our goals;

b. Non-affective destructiveness is inborn, physiologically generated; is essential for alimentation andsurvival;

c. Hostile aggression (HA)* (the over-arching trend from annoyance to anger, and on to hostility \& to rage). This overarching trend contains the sub trend

d. Hostile destructiveness (HD) (the sub trend that extends from hostility to hate and rage).

e. HA is not inborn; and it is not biologically activated; the mechanism for its generation is inborn; this mechanism is activated by an experience of psychic pain "unpleasure"); Psychic Pain is required for the generation of HA; Excessive Psychic Pain is required to generate HD; Psychic Pain gives to aggression the affective quality characteristic of annoyance to anger, and as it crosses the critical threshold, e.g., "This is too much!", "You have gone too far!", Excessive Psychic Pain does so for hostility, hate and rage.

f. Most critical: HD can be moderated or it can be heightened by experience [12]. Thus, experience is the foremost generator of Hostile Destructiveness (HD). I should note that the cardinal hypothesis "Unpleasure (experience) generates HD" has its biological basis in the "irritability of the protoplasm" [13].

These findings and this line of thought have led me to ask: If Freud's answer to Einstein's question is wrong, then, what prime hostility-generating experiences cause destructiveness in our patients and because large group conflict that create "the countless cruelties in history" we have witnessed and read about?

\section{The Vicissitudes of Human Narcissism}

The vicissitudes of narcissism are a pre-eminent experiential potential generator of human conflict. Narcissism is a psychodynamic state-of-being experienced by an individual as well as by a group. In 1914 Freud [16] conceptualized the dynamics of narcissism in the individual. In 1921 (Group psychology and the analysis of the ego) and in 1932 (Why War), Freud [17] spoke of the narcissism of groups. In 1932, Freud [1] held that groups organize around a commonality that leads 
to its cohesion, and in doing so, as Volkan [18] has extensively written about, each community develops a specific "group identity". Communities forge their own specific "group identity", a specificity that I propose is forged out of its $100 \%$ biological commonality to all humanity and perhaps $7 \%$ ideological specificity to each individual group. Of course there is no way to determine the degree to which humans in different ethnic groups, races, religions are truly different; but groups are wed to their respective ideologies $[19,20]$ which I propose holds the essence of their perhaps 7\%ideological differences. This is what led Freud to speak of "the narcissism of minor differences": my proposed ideological-based $7 \%$ that leads to a perceived greater than real difference among peoples [4,21].

\section{The Complexity of Human Narcissism}

Freud [16] taught us that narcissism is the investment of libido in oneself; in fact, he held in 1920 that the ego, i.e., the self is the reservoir of the libido. Already in 1914, Freud [16] had proposed that primary narcissism is inborn, and that secondary narcissism is acquired. Primary narcissism is evident in the newborn's self-focused behaviors. I believe it derives from a biologically mandated sense of self-preservation that is observable in the universal animal "fight or flight" behavior [22] in the face of danger. But, the form of narcissism that most has a bearing on conflict and war is that which we Humans acquire: our secondary narcissism. To operationalize, dissect this secondary narcissism, we might say that it is constituted from three sources: (1) withdrawal-reinvestment narcissism; (2) achievement-derived narcissism; and (3) inherited narcissism.

\section{Withdrawal-reinvestment narcissism}

There are 2 types:

a) As Freud [16] held in 1914, when an individual feels depressed or physically ill, self-protectively here-turns toward himself the libido he has invested in others. When health is restored, the libido is reinvested in these loved-objects. This transient "withdrawal-reinvestment" narcissism retains its character of 'good mental health'.

b) When a libidinal object is intensely hurtful to us, we withdraw the libido invested in this person and reinvest it in oneself. When in childhood, libidinal objects are intensely and too frequently hurtful to the child, the dynamics of this "withdrawal-reinvestment" narcissism tend not to be transient; critical is that it leads to a false heightened-valuation of the self and the active devaluation of the hurtful other. This brings with it the experience of a self that is "better than" the de-invested other. That is, it yields a "heightened/hyper-narcissistic skew", which may generalize into hyper-valuation of self and undervaluation of others.

\section{Achievement-Derived Narcissism}

Leads to a degree of heightened-narcissism and well-being. Such heightened-narcissism can become hyper-narcissism when one's own efforts, perseverance and chance lead to high achievement. Such high achievement leads many individuals to make meaningful contributions to advances in civilization that benefit humanity. But not all achievement-derived hypernarcissism has served humanity benevolently. Many who have amassed stature or a fortune have only too often put it to serve their own hyper-narcissistic self-interest. I would venture to wonder if in their childhood many of these individuals did not experience their primary narcissism to be well mirrored and secure; nonetheless, being resourceful and intelligent, they have buttressed their vulnerable primary narcissism by seeking power over others and exploiting them.

\section{The Hyper-Narcissistic Skew}

When large-groups seek power over or exploit others, these behaviors are based on a collective hyper-narcissistic skew that affirms the conviction that "we are better than they are". Qualitatively and quantitatively, such hyper-narcissistic skew may be driven by

a. Antisocial, hyper-narcissism or by

b. Malignant hyper-narcissism.

a. Antisocial hyper-narcissism characterizes the behavior of large-groups (or well-known individuals) that behave in ways that disregard moral and even legal rules of conduct that end up causing injury to others. Among groups, racism for example and ethnic degradation bear witness to antisocial hyper-narcissism. Among individuals, much of the last decade's economic recession can be laid at the feet of their antisocial narcissism.

b. Malignant hyper-narcissism can breach the bounds of reality. Hyper-narcissist leaders of large-groups consider themselves to be uniquely superior individuals far surpassing others. Hitler and Stalin exemplified malignant hypernarcissism; Hitler went so far as to speak of the Germans as "the master race" and, as Koenigsberg tells us [19], saw Jews as inferior toxic viruses. But while narcissism is subject to inflation, it is also subject to deflation, that is, to injury.

\section{Injury to Narcissism}

Bearing in mind the multi-trends theory of aggression's assertion that "psychic pain generates hostile destructiveness", I draw attention to the fact that the critical causative factor that leads to a sense of narcissistic injury is psychic pain. Narcissistic injury, which brings with it psychic pain is part of everyday life. Subjectively and objectively, however, not all injury is equivalent. The questions are: (a) what is the nature of the psychic pain? (b) What are the conditions that cause the psychic pain? (c) Who causes the psychic pain? (d) How intense, how exploitative, how pejorative is/was it? And, (e) how is it interpreted by the injured individual or group? Again, operationalizing, we can catalogue injury to narcissism along a spectrum: (1) benign, (2) hostile, and (3) pernicious. Among groups, 


\section{Benign narcissistic injury}

Collective sports are a prime example of group-inflicted narcissistic injury. The winning team rejoices. The losing team may experience loss quite painfully; but the injury is part of the game. No team avoids a game due to the risk of sustaining such a narcissistic injury.

\section{Hostile narcissistic injury}

Collectively, humans find ways of being hostile to one another as they compete to achieve some goal in sports and in war. In this, sometimes the winner group may sadistically vaunt its success to boost its stature by undermining that of their 'enemy'. Licking one's wounds of war by glorifying their cause is a defense that has long worked well-although this defense seems to be working less well during and since the recent military engagements in the Middle East.

\section{Pernicious narcissistic injury}

When a group-in-power harshly humiliates, degrades and/ or exploits a victimized group, it causes this group an intense collective level of psychic pain that inscribes the specific or collection of injuries sustained into the group's identity, whereby it becomes what Volkan $[23,24]$ has specified as a "chosen trauma". Civilization's well know examples of such large-group pernicious narcissistic injury include colonialism, slavery, malignant prejudice, and the world scattered criminal degradations and humiliations that end up in genocide. As Kiernan [25] has detailed in a large volume, while genocides go back to 7,000 years ago, from the fifteenth century on, with the dawn of the modern era, "advances in transportation and firepower frequently bring into collision societies separated by the requisite technology chasm", i.e., the stronger, the prepared, attacking the weaker or unprepared. Speaking of the 20th Century, Kiernan asserts that it was "a new, even darker, even more extensive century of genocide during which at least 30 million people perished in genocides across the globe".

\section{The Cyclicity of Hyper-Narcissism and Narcissistic Injury}

I especially want to draw attention to this cyclicity. Both, hyper-narcissism and narcissistic injury, create reactivities in groups that motivate conflict and war: Hyper-narcissism, hostile, but specifically malignant hyper-narcissism commonly activates the "hyper-narcissistic skew" ("We are better than them!") which fuels malignant prejudice against an enemy that commonly gives motive-power for war. But most critical is the fact that narcissistic injury too tends to generate its own "hyper-narcissistic skew"-"we the good; they the bad, who hurt us"-which in time motivates retaliation be it in uprisings, retribution/revenge, revolutions and wars.

\section{How Does the Narcissistically Injured Become the Injury Perpetrator?}

"Critical to my thesis is that while it would seem that powerful hyper-narcissistic powers could have their way in human relations, we have seen that powerful victors of today can never be assured that their victory over another will now settle matters for ever. In fact, history has shown that rather commonly, today's narcissistically injured, i.e., defeated or oppressed has on many occasions in the course of history become tomorrow's hyper-narcissistic attacker. How does the narcissistically injured group become the hyper-narcissistic injury perpetrator?

As Volkan [23] has proposed, a past intense psychic group injury imprints in the psyche of the group and becomes a "chosen trauma". Volkan's concept, a "chosen trauma", has much merit as a phenomenon, one that conveys a specific meaning with large generative potential for the group that experiences it. It is "chosen" in that, it is selected as a crucial formative and identifying event in the history of the group; it reflects the group's consciously selecting the trauma as highly specific to its history which then further shapes the traumatized group's identity. I think Volkan is right in speaking of it so when it becomes used as a motive for mobilizing a group's energies, fears, or hate in support of a cause deemed advantageous to the injured group-be it for purposes of fund-raising to help secure funds for a group's self-defense, or to support a smear campaign against the trauma perpetrator, or of course, in support of retribution and revenge (such as, for example, to mold devout members of a group into terrorist attackers).

But I want to emphasize a less identified aspect of Volkan's concept. A "chosen trauma", in addition to being a large-group marker, is especially an "identity-modifying trauma", both of the large-group identity, but also of each of its individual members' identity. Both, the individual and the large-group's essential identity, which have evolved over time from the beginning of the existence of each, now get further modified by the incorporation of the experience of the enormous trauma in its individual and collective self-definition. The fact is that more than being "chosen", such trauma cannot be shaken from one's mind, it exists in the mind of both, the individual and the group, even when one might wish to never think about it again due to both, its conscious and unconscious timeless painful reverberations.

The identity-modifying trauma is acknowledged and remembered as a profoundly injurious, irresolvable trauma. It is mourned by the group whereby it is further integrated into the group identity, becoming an activator of the group's collective memory, sentiment and loyalty. Historically then again, as Volkan [24] recently proposed, it becomes a banner around which the injured group gathers. As such, the past injury collectively generates psychic energies that enhance attitudes 
of self-valuation within the traumatized group. However then, under conditions favorable for it, the mobilization of a group's psychic energies may foster the elevation of its narcissism excessively which fosters the hyper-narcissistic skew: "selfvaluing" energies and attitudes for group members, and "other-devaluing" energies and attitudes for the former injury perpetrator. The activation of this hyper-narcissistic skew and the psychic energies it generates, and the potential physical energies that go with it, will be facilitated by reminder-resonant events and anniversaries meaningful to the group.

In general then, the greater the activation of the group's trauma-generated psychic energies, the greater the inverse relation, the more positive the narcissistically injured group's "self-valuation" and the more negative the trauma-perpetrator "other-devaluation", the more will the group's narcissism become revitalized, self-convincingly consolidate and the more likely it will evolve into group-perceived hyper-narcissism, we are better, the righteous, than they! And when, as has happened only too frequently among large-groups, the accumulated highlevel-hostile destructiveness it harbors gets mobilized, the hostilification of the group's hyper-narcissism may devolve it into one of the malevolent forms of hyper-narcissism. This was amply demonstrated in the Third Reich's over-reaching ambitions in WWII. And this is where the "complement of hypernarcissism and narcissistic injury" plays itself out between groups: Today's injured group may well become the hypernarcissistic group that tomorrow, will inflict narcissistic injury on the former narcissistic injury perpetrator.

It may become a vicious cycle between neighboring groupsthe neighbor proximity having dramatically enlarged over time as "the world has gotten smaller"-again, as was seen in Europe during the last 150 years in the series of wars between Germany and its Allies and France and its Allies: first during the FrancoPrussian War of 1870-1871, then in WWI (1914-1918) and then again, in WWII (1939[1940]-1945)" [12]. In time, in the midst of other social contributing factors, the previously narcissistically injured has often subsequently become the hyper-narcissistic injury perpetrator. The German launching of World War II is an example of this cyclicity; so are, among others, the HinduMuslim reciprocal attacks in the India-Pakistan region that have occurred over centuries [26], as are centuries of Hutu-Tutsi, reciprocal wars and genocides [25].

There are many issues that contribute to the generation of large-group conflict on which psychoanalysis-and social psychology-can shed some light which, as the League of Nations and Einstein believed, could be of much value to society and, especially to those authorities in society who deal with social conflict. In War is Not Inevitable I have taken up several more such issues, some of which I will now comment on briefly, and then I will close, elaborating a bit more on one issue in which have worked extensively.

\section{The Role of Prejudice}

In my studies on prejudice [27-30] I have recognized that 2 processes obligatory for the healthy development of self and one's primary relationships makes us all have prejudices:

a) Stranger anxiety: looking at a person the infant has not seen with some regularity, he feels anxious. Anxiety-driven, he turns away from the "stranger", and manifests relief when he sees one of those who from birth-on have become familiar to him. I have proposed that stranger anxiety furthers the child's attachment to those who care for him and fosters his becoming a member of his specific family; but this is complemented by his turning away from strangers. In other words, stranger anxiety fosters attachment, serving family formation which is the building block of community formation, and simultaneously establishes "anxiety-producing others" [31].

b) The second factor is identification with those to whom the child attaches which leads to his developing a kinship with and to feel secure with people like his own family, like people of his own community. Both developmental obligatory factors contribute to our normal benign tendency to prefer to be with those like ourselves.

But we know that not all prejudice is "benign", that some prejudice is "hostile," even "malignant". As I attempt to detail in complex diagram A, two factors which impact humans predominantly lead to the forging of their "benign prejudice" into "hostile" and "malignant prejudice". These factors are (1) their accumulated high-level hostility and hate, and (2) their rearing and education. Essentially, by virtue of (1) traumatizing experiences that cause humans, individually and in groups, much pain and generate in them hostile destructiveness (HD), by means of several psychic strategies-foremost defense mechanisms-leads them to attach their HD to selected "strangers". Equally weighty, (2) variable education, ethnic, religious, and nationalistic, which further mold both an individual's and a group's identity may indoctrinate them into "hostile prejudice", and especially when extremist, may lead to "malignant prejudice" [28,29] (Figure 1). But there are other reactivities that lead to conflict.

\section{Large-Group Psychodynamic Reactivities Contribute to the Generation of Conflict}

These reactivities that contribute to conflict invariably act in conjunction with the vicissitudes of narcissism. Such are the (1) need for power, (2) greed, (3) envy, (4) the need to blame others, and (5) the need to have enemies-each of which can lead to oppression, even the destruction of others. Might not groups like individuals begin life more or less helpless, vulnerable and often anxiety-laden? The degree to which a child will/will not evolve into an adult who manifests such negative character features depends in large measure on the way the child is cared for, reared and educated. So too, anticipating what I say later about what happened in Nazi Germany, I assert that groups acquire negative 
(and positive) characterologic reactivities depending, not only on the large events that befall large-group life, but also on how the young in large-groups are collectively reared and educated. I will say more about this below.

\section{The Aftermath of War Shapes the Future}

Of large consequence to the cyclicity of wars, bearing in mind the cyclicity of hyper-narcissism and narcissistic injury, I ask, "How do we humans deal with one another after a war, after a bloody and invariably treacherous conflict comes to a close?" Examining the aftermath of World Wars I and II, critical differences exist in the way, after each war, the victors reacted toward the enemy they defeated. It is well-documented that the defeated Germans were painfully humiliated by the harsh Treaty of Versailles that closed WWI-the French intending to disable Germany so that it could never again fight a war-which became an explanation for the consequent societal turmoil Germans experienced. One cannot but wonder if there ports left by those close to the post-war WWI armistice process were not lost on the end-of-WWII negotiators who had learned the critical lessons brought to light from what happened after World War I. The fact is that how the victors dealt with the defeated after WWI stands in sharp contrast with how the victors treated the defeated after World War II. Let me elaborate.

\section{Can One Compare Dynamics of One War with Another?}

Of course, the nature and dimensions of post-war major factors that influence any nation's post-war recovery are never fully comparable. For example, within a decade, World War I was followed by a catastrophic world-wide economic collapse which was not the case following World War II. Nonetheless, I am among those who advance the view that, how the victor deals with the enemy he defeated is of enormous consequence to how the two blocks of nations will co-exist for long after the military conflict has ended. For example, among other things, where as the victors of WWI wanted to disable Germany from ever being able to again wage war; the victors of WWII helped Germany regain its economic and social health in good measure by implementing the Marshall Plan side by side with a program of Denazification. Since time immemorial, how individuals as well as large groups have dealt with those they defeated has created international peaceful co-existence or cyclically reciprocal misery!

\section{What Can We Do Toward Reducing Human Conflict}

In 1932, Freud was not totally pessimistic. He put forward the hypothesis that "For incalculable ages mankind has been passing through a process of evolution of cultures (of civilization)[and] one thing we can say: whatever fosters the growth of civilization works ...against war". As civilization grows, despite our terrifying ability to destroy one another in ways never before known, we may be at the best place we have yet been, given that, (a) affordable communication and travel connect us universally; (b) economies are nearly universally interconnected; (c) more and more we judge the criminality of genocide, (d) the suffering, devastations and costs of war, (e) the immorality of exploiting human beings;

\section{And Since the Enlightenment}

Disappointments notwithstanding, we have progressively seen conflict-driven efforts that have led to(1) The American "Bill of Rights"; then(2) The French "Rights of Man";(3) Communist revolutions-despite communism failure to recognize the merits and powerful play of normal healthy narcissism in humans, a major short-sightedness; (4) the century-in-the-making "Women's Liberation Movement"; and while much racism and inter-ethnic conflict continue, we are on the move toward The "Universalization of 'Human Rights"' which, much driven by Eleanor Roosevelt was adopted by the UN in 1948. Forgive my taking note of the obvious, that we cannot bring about "the growth of civilization" in terms of years, but rather in terms of generations, of centuries. I hold that civilization is on a trajectory toward improving Homo sapiens' stay on earth and survival.

\section{Among the Strategies Available to Us to Prevent Wars: Some are Old and Some are New.}

Just touching on these here, in War is Not Inevitable... I detail "methods we have been employing that work" and from all indications will continue to work: Nations are forming peacefully co-existing communities like never before; the largest unification of nations prior to the United Nations, the League of Nations, spearheaded by Woodrow Wilson at the end of WWI, at its largest number consisted of 56 nations. Today, the United Nations is constituted of 198 nations. Human rights organizations are numerous and multiplying, so are ethno-pluralistic communities, and on a smaller scale, inter-faith alliances. And efforts continue toward increasing the universalization of formal public education.

Considering "methods of co-existing that have been tried, do work, but not well enough", we seem to be on a trajectory toward furthering their effectiveness. The UN's 1948 "Universal Declaration of Human Rights" as well as the criminalization of Genocide while remarkable achievements in being instituted by the United Nations, have however, been slow in being enforced. Also after much delay, it is at the turn into the 21stcentury, that "The International Criminal Court" began to act. On the question of Preventing Genocide, in A Problem from Hell, Samantha Power [32], current U.S. Ambassador to the United Nations is critical of US passivity holding that, as does Chris Hedges [33], strong nations must act to prevent genocide. This challenge they say must be undertaken despite the uncertainties it carries, the risks and the difficulties! And there have been increasing engagement by the US, the European Union, the African Union, and the UN in intervening in such genocide prevention, e.g., in Sudan, in Syria, and Iraq where currently Isis/Isil is boldly engaged in a campaign of terror.

Complementing Power's thesis, David Hamburg in Preventing Genocide [34], a volume written a few years later, 
culled from his work at the United Nations and at the European Union details credibly feasible, constructive, progressive strategies that Hamburg believes present "Practical Steps toward Early Detection and Effective Action". In concluding my book, I assert that we Humans can and will always come up with "new, promising methods/strategies we will try". I want to address one such a promising strategy.

\section{One Among "Promising Methods/Strategies We Must Try"}

In my last chapter, I take up an issue our field must address; an issue Freud clearly recognized (1933). Three of our best recent thinkers, Hannah Arendt, Primo Levi, and Saul Friedlander wrote that the Holocaust perpetrators were "ordinary people". As has been argued, Arendt [35] seemed to venture the view that the Nazi criminals "were not psychopathic". I question Arendt's diagnosis, asking: "What are 'ordinary/average' people?" "Is a person who commits a crime 'ordinary'?" I report that as Karl Heinz Brisch wrote [36], since the 1600s according to Rutschky [37], child rearing ideology prepared German children to be unconditionally obedient, in the words of the Oxford English Dictionary, "passively obedient". So reared, German children became well-disciplined adult citizens! But rearing children to 'unconditional obedience' requires that children yield their sense of autonomy and of moral integrity in the face of demands made by external authority [31]. Then, under the leadership of an antisocializing authority, these passively obedient citizens did what they were told to do regardless of its morality or lawfulness-they murdered Jews, Roma, Seventh Day Adventists, babies, women and old people, not for what they did, but because of who they were! With palpable painful dismay and courage, German colleagues, e.g., my dear friend from Munich Lotte Koehler (in many personal communications), our esteemed colleague from Frankfurt Werner [38,39], Karl Heinz Brisch from Munich [36], and Berliner Herman [40] have essentially said that such rearing to passive obedience made German youth capable of such genocidal behaviors. As a psychoanalyst, I assert that such anti socialization of a large grouped to those of the group who committed crimes against humanity to have become a collective of 'psychopathic' individuals.

It is established that certain Child Rearing Ideologiescan rob individual human beings of their autonomous sense of self, of selfdetermination, autonomous judgment, and "moral imperative", corrupting their sense of moral responsibility, as Arendt found in Eichmann [35]. Research and clinical experience have made clear to us a tenet increasingly established in psychoanalysis: that our child rearing methods determine what kind of adults our children become. Recognizing that Psychoanalysis has learned more during the 20th century about how to optimize a child's development than had been known during more than 20 centuries that preceded it, this compelled my research on parenting. This research taught me that we can spell out strategies for parenting education which aim at achieving the optimization of children's mental health development. This has pushed me to assert that there is a universal need for formal parenting education for children in Grades $\mathrm{K}$ through 12-our next generation of parents-as well as for "already parents", and all types of child caregivers, daycare workers, teachers, etc. To this end, my team and I have developed parenting education materials aimed at achieving the goal of rearing emotionally healthy, empathic and socially and morally responsible children.

In parallel with our own efforts, I know colleagues in the U.S. and in Europe who, using strategies they have individually devised are engaged in similar early child hood prevention. Among these, I want take note of two colleagues arduously so engaged: Marianne Leuzinger-Bohleber who has spearheaded multi-site programs that aim at early intervention with disadvantaged families [41], and Karl Heinz Brisch who has instituted early preschool and school programs, his Baby Watching B.A.S.E. , in many sites in Germany and Austria, in London and elsewhere, and I want especially to note that this German colleague just recently helped Israelis launch his B.A.S.E. prevention program in Tel Aviv. (In fact, I can tell you that in my emails with both, Kalle Brisch and Assaf Levin, each expressed enthusiasm and heartwarming appreciation of their collaboration, the thoughtful and responsibly committed German and the welcoming and thankful Israeli!)

\section{Conclusion}

Let me assure you that I am doing no more than following Freud's 1933 foresight which he enunciated in his New Introductory Lecture 34, on Explanations, Applications and Orientations: "But there is one topic which I cannot pass over so easily-not, however, because I understand particularly much about it or have contributed very much to it. Quite the contrary: I have scarcely concerned myself with it at all. I must mention it because it is so exceedingly important, so rich in hopes for the future, perhaps the most important of all the activities of analysis. What I am thinking of is the application of psychoanalysis to education, to the upbringing of the next generation. [And Freud continues,] I am glad that I am at least able to say that my daughter, Anna Freud, has made this study her life-work and has in that way compensated for my neglect" [42]. And I, the author of this document can say, that it is a privilege to try to contribute to the realization of Freud's vision.

\section{References}

1. Freud S (1932) Why War? Standard Edition 22:197-215.

2. Freud S (1920) Beyond the pleasure principle. Standard Edition 18: 1-64.

3. Freud S (1925) Some psychical consequences of the anatomical distinction between the sexes. Standard Edition 19: 248-258.

4. Freud S (1930) Civilization and Its Discontents. Standard Edition 21: $59-145$

5. Freud S (1937) Analysis terminable and interminable. Standard Edition 23: 211-53. 


\section{Psychology and Behavioral Science International Journal}

6. Bibring E (1941) The development and problems of the theory of the instincts. Int J Psycho-Anal 22: 102-131.

7. Fenichel O (1945) The Psychoanalytic Theory of Neurosis. New York: Norton.

8. Hartmann H (1950) Psychoanalysis and developmental psychology. Psychoanalytic Study of the Child 5(1): 7-17.

9. Simmel E (1944) Self-preservation and the death instinct. Psychoanalytic Quarterly 13: 160-185.

10. Waelder R (1956) Critical discussion of the concept of an instinct of destruction. Bulletin of Philadelphia Association Psychoanalysts 6: $97-$ 109.

11. Parens H (2008) The Urgent Need for Universal Parenting Education A Documentary, PA.

12. Parens H (2014) War is Not Inevitable: On the Psychology of War and Aggression. Lanham, MD: Lexington Books.

13. Parens H (1979) The Development of Aggression in Early Childhood Revised Edition (2008). Lanham, MD: Jason Aronson/Rowman \& Littlefield Publishers, Inc.

14. Parens H (1993) Toward preventing experience-derived emotional disorders: Education for Parenting. In: Prevention in Mental Health, $\mathrm{H}$. Parens \& S. Kramer, pp. 121-148.

15. Parens H (2000) The Multi-Trends Theory of Aggression. A PowerPoint document (unpublished).

16. Freud S (1914) On narcissism: An introduction. Standard Edition 14: 69-102.

17. Freud S (1921) Group psychology and the analysis of the ego. Standard Edition 18: 67-143.

18. Volkan VD (1999) Psychoanalysis and Diplomacy: Part I. Individual and large group Identity. Journal of Applied Psychoanalytic Studies 1(1): 29-95

19. Koenigsberg RA (1975) Hitler's Ideology: A Study in Psychoanalytic Sociology. New York: The Library of Social Science.

20. Koenigsberg RA (2011) Why Do Ideologies Exist: Psychoanalytic Interpretation of Culture \& History. In: Ideologies of War Newsletter

21. Freud S (1918) The Taboo of Virginity, SE 11, p 199.

22. Cannon WB (1929) Bodily Changes in Pain, Hunger, Fear, and Rage. New York: Appleton.

23. Volkan VD (1991) On chosen trauma. Mind and Human Interaction $3: 13$

24. Volkan VD (2010) A Discussion: Psychoanalytic considerations on large-group psychology. Fall Newsletter of the American College of Psychoanalysts 44: 5-7.

25. Kiernan B (2007) Blood and Soil-A World History of Genocide and Extermination from Sparta to Darfur. Newhaven, CT: Yale University Press.

26. Akhtar S (2005) Hindi-Muslim relations: India. In: Freud along the Ganges: Psychoanalytic Reflections on the People and Culture of India, New York: The Other Press, pp 91-137.
27. Parens H (1999) Toward the prevention of prejudice. In: En El Umbral Del Milenio (At the Threshold of the Millennium), Vol. II, ed. M. R. Fort Brescia and M. Lemlij, Prom Peru: SIDEA pp 131-141.

28. Parens H (2007a) Toward Understanding Prejudice - Benign and Malignant. In: The Future of Prejudice: Psychoanalysis and the Prevention of Prejudice, New York: Rowman \& Littlefield Publishers, Inc pp 21-36.

29. Parens H (2007b) Malignant Prejudice - Guidelines toward Its Prevention. In: The Future of Prejudice: Psychoanalysis and the Prevention of Prejudice, New York: Rowman \& Littlefield Publishers, Inc pp 269-289.

30. Parens H (2007c) The Roots of Prejudice: Findings from Observational Research. In: The Future of Prejudice: Psychoanalysis and the Prevention of Prejudice, New York: Rowman \& Littlefield Publishers, Inc, pp 81-95.

31. Parens H (2011) Handling Children's Aggression ConstructivelyToward Taming Human Destructiveness. Lanham, MD: Jason Aronson.

32. Power S (2002) A Problem from Hell - America and the Age of Genocide New York: Basic Books. Harper Perennial edition, 2007.

33. Hedges C (2002) War is a Force that Gives Us Meaning. New York: Anchor Books

34. Hamburg DA (2010) Preventing Genocide: Practical Steps toward Early Detection and Effective Action. Boulder, CO: Paradigm Publishers. International Journal of Applied Psychoanalytic Studies 9(4): 366-368.

35. Arendt H (1977) Eichmann in Jerusalem-A Report on the Banality of Evil. London: Penguin Books Ltd., 2006.

36. Brisch KH (2014) Early Parenting and The Prevention of Disorder Psychoanalytic Research at Interdisciplinary Frontiers, ed, RN Emde \& M Leuzinger-Bohleber, pp 203-215. London: Karnac Books Ltd.

37. Rutschky K (2001) Schwarze Pädagogik. Quellen zur Naturgeschichte der bürgerlichen Erziehung. Munich, 8th ed.

38. Bohleber W (1995) The children of the perpetrators-The after-effects of National Socialism on the following generations. Presented in Toronto, May 4, 1995.

39. Bohleber W (2010) Destructiveness, Intersubjectivity, and TraumaThe Identity Crisis of Modern Psychoanalysis. London: Karnac Books Ltd.

40. Beland H (2015) Collective Mourning-Who or What Frees a Collective to Mourn. In: Hostile and Malignant Prejudice: Psychoanalytic Approaches, ed. C. Levitt, chapter 4. London: Karnac (in press).

41.Emde RN, Leuzinger-Bohleber M (2014) Early Parenting and The Prevention of Disorder Psychoanalytic Research at Interdisciplinary Frontiers. London: Karnac Books Ltd.

42. Freud S (1933) New Introductory Lectures On Psycho-Analysis: XXXIV. Explanations, Applications and Orientations, Standard Edition22:136-157. 
Your next submission with Juniper Publishers will reach you the below assets

- Quality Editorial service

- Swift Peer Review

- Reprints availability

- E-prints Service

- Manuscript Podcast for convenient understanding

- Global attainment for your research

- Manuscript accessibility in different formats ( Pdf, E-pub, Full Text, Audio)

- Unceasing customer service

Track the below URL for one-step submission https://juniperpublishers.com/online-submission.php 